\title{
An epidemiological study of Wilson's disease in the Republic of Ireland
}

\author{
M Reilly, L Daly, M Hutchinson
}

\begin{abstract}
In a population based study of the prevalence of Wilson's disease in the Republic of Ireland from 1970-89, 26 definite and probable cases were ascertained. The adjusted birth incidence rate was $17 \cdot 0$ per million live births $(95 \%$ (confidence interval 9.9 to $27 \cdot 2$ )) for the 20 year period 1950-69. The gene frequency was $0.41 \%(95 \%$ (confidence interval $0.31 \%$ to $0.52 \%$ ) indicating that one in 122 of the population was a gene carrier. Allowing for a maximal degree of consanguinity, the gene frequency is reduced to $0.36 \%$ and the proportion of heterozygotes to one in 139 of the population. The consistency of the adjusted birth incidence rates over the decades 1950-59 and 1960-69 suggests a high degree of ascertainment of diagnosed cases of Wilson's disease.
\end{abstract}

( $(\mathcal{N}$ Neurol Neurosurg Psychiatry 1993;56:298-300)

Wilson's disease (hepatolenticular degeneration) is an inborn error of copper metabolism which is inherited in an autosomal recessive manner. ${ }^{12}$ Despite often quoted worldwide prevalence figures of 30 cases per million population $^{3}$ the epidemiological studies on this disease are neither numerous nor completely satisfactory. ${ }^{24-13}$ Few have been complete population based studies.

Because of deficiencies in the epidemiological studies to date, we decided to carry out a population based study of Wilson's disease in the Republic of Ireland covering the years 1970-89. Ireland is suitable, being geographically distinct, having a low rate of immigration, low consanguinity rate and a well developed health service with reliable medical records for the period under study.

\section{Methods}

CASE ASCERTAINMENT

Patients with a diagnosis of Wilson's Disease or who died with that condition in the period 1970-89 inclusive were identified from (a) the Hospital Inpatient Enquiry Scheme (HIPE) of the Health Research Board of Ireland, a central coding system covering most hospitals (other than private hospitals) in the country; (b) all practising neurologists, paediatricians, gastroenterologists, general physicians with an interest in gastroenterology and pathologists; (c) all death certificates 1970-89; (d) all laboratories in which measured copper and caeruloplasmin levels were measured; and (e) Dr JM Walshe, Cambridge, United Kingdom. The families of all patients, living or dead were contacted to construct family trees and ascertain possible further cases. The diagnosis of Wilson's disease had in all cases been made by a hospital consultant and was based on characteristic clinical and biochemical findings. Cases were subdivided as (a) primary cases-when the patient was the index case diagnosed in a particular family; (b) secondary definite cases diagnosed as typical Wilson's disease and determined by screening the family after the index case had been diagnosed; and (c) secondary probable cases who had died of an illness consistent with Wilson's disease before the diagnosis of the disease in the index case.

\section{STATISTICAL METHODS}

Prevalence for patients with Wilson's disease alive during the 20 year period was calculated in relation to the population obtained from censuses carried out in 1971, 1979, 1981 and 1986. 'True prevalence' 10 was also calculated using the same denominator but using the numerator as the number of patients alive with Wilson's disease on the census day plus the number of people alive who were subsequently diagnosed as having the illness.

Although ascertainment of cases was as complete as possible, crude birth incidence figures (number of cases born in a period divided by the total births in the period) underestimate the true incidence. We have used the term birth incidence to denote this quantity, as is standard in genetic applications. ${ }^{14}$ The measure refers to the proportion of births with the particular genetic condition, even though identification of these individuals is not made at birth. Some epidemiologists prefer the term birth prevalence. ${ }^{15}$

Because some affected individuals remained asymptomatic and undetected by the end of the study ascertainment period of 1989 , a birth incidence rate adjusted for the probability of detection was calculated. Crude and adjusted birth incidence were estimated for the two decades 1950-69. The age-specific 
probability of detection of a case of Wilson's disease was based on the age of diagnosis of the 12 detected cases born before 1955 as inclusion of later cases would seriously overestimate the probabilities. An adjusted number of cases born in each year from 1950-69 was obtained by dividing the observed number by the appropriate probability of detection. For example, there were three cases born in 1960, and these would have been aged 29 at the end of the study period in 1989 . By age 29 , according to our estimates, $75 \%$ of all cases would be detected so that the adjusted number of cases is four (3/0.75).

Confidence intervals for the adjusted birth incidence were based on a Poisson distribution for the number of observed births, with the confidence limits multiplied by the percentage increase between the observed and adjusted births. Gene frequencies $(q)$ were calculated from the adjusted birth incidences (I) using the Hardy-Weinberg law ${ }^{16}\left(q^{2}=\mathrm{I}\right)$, and the proportion of heterozygotes was estimated as $2 q$. Confidence intervals were obtained by applying these formulas to the confidence limits for the birth incidences. The Hardy-Weinberg law assumes a randomly mating population, that is, without consanguinity. Consanguinity is probably low in Ireland but estimates of the minimum possible gene frequency and the proportion of heterozygotes in the population were calculated using the highest population coefficient of inbreeding $(F=0.001)$ likely to hold for any western European population. ${ }^{1416}$ The gene frequency $(q)$ was calculated from $I=q^{2}+$ $F q$, and the proportion of heterozygotes as $(1-F) 2 q$.

\section{Results}

\section{CASES ASCERTAINED}

In the period $1970-89,26$ cases of Wilson's disease were determined: 15 primary, six secondary definite and five secondary probable cases. Twenty four of the 26 cases were detected from the HIPE system, the two others from one consultant neurologist. Other means of detection yielded index cases already determined by the HIPE system (death certificates: 3; laboratories: 10; neurologists: 10 ; gastroenterologists: 11 ; paediatricians: 1; pathologists: 1 ; and Dr J M Walshe: 1).

Prevalence per million population for the census years was $1971: 0 ; 1979: 3.5 ; 1981: 3.2$; and 1986:3.6. True prevalence for the same periods was 1971:6.7; 1979:5.6; 1981:4.9; and $1986: 4 \cdot 5$.

\section{BIRTH INCIDENCE RATES}

The mean age of onset of symptoms was 16.5 years (median 15.5 years, range $10-40$ years). The mean age at diagnosis was 18.9 years (median 16 years, range $11-40$ years).

The years of birth of the 26 ascertained cases were, before 1949: 5 ; 1950-54: 7 ; 1955-59: 3; 1960-64: 6; 1965-69: 1; and 1970 onwards: 4 . For birth incidence estimations only the 17 cases born in 1950-69 are included. Crude and adjusted birth incidence figures per million population were 1950-59: crude $16 \cdot 1$; adjusted 17.6 (95\% CI: 8.4 to 32.3), 1960-69: crude 11.3; adjusted 16.4 ( $95 \% \mathrm{CI}: 6.6$ to $33 \cdot 9$ ). There was no significant difference between the incidence rates in 1950-59 and 1960-69 though the rate did drop slightly. Over the entire period the (adjusted) incidence of Wilson's disease was $17 \cdot 0$ per million births. (95\% CI: 9.9 to 27.2). Using the Hardy-Weinberg law, this corresponds to a gene frequency of $0.41 \%$ (95\% CI: 0.31 to 0.52 ) and a proportion of heterozygotes in the population of $0.82 \%$ ( $95 \%$ CI: 0.62 to 1.04 ). This means that 1 in 122 of the population carries the gene. These figures may be somewhat inflated because random mating is assumed, and allowing for a maximal likely degree of consanguinity, probably much too high for Ireland, the gene frequency reduces to $0.36 \%$ and the proportion of heterozygotes to $0.72 \%$ ( 1 in 139 of the population). On the basis of our data, these must be considered as the lowest possible figures for this country.

\section{CLINICAL AND FAMILIAL ASPECTS}

Other than familial cases, there was no particular clustering by geographical distribution. The main system involved at onset was hepatic, $54 \%$, neurological or neuropsychiatric $27 \%$, purely psychiatric $12 \%$, haematological $7 \%$. Screening of siblings and parents had been performed in 13 of the 15 index case families; in two families screening was refused and we are not aware of any symptoms of disease in these two families. Eleven secondary cases had been determined at screening, six of these being confirmed by clinical investigation, five (secondary probable) cases on the basis of previous death of a sibling and in one case a paternal uncle, from an illness consistent with Wilson's disease. None of the families contained a first cousin parental marriage, but in one family the great-grandparents were first cousins. The ratio of cases to total sibling numbers was $26 \%$, consistent with autosomal recessive inheritance. Although attempted in some families, cousin screening was not adequately performed in any family.

\section{Discussion}

Although prevalence figures are of limited use in Wilson's disease because of the high mortality due to disease severity and delayed diagnosis, it may be useful to compare the present findings to other European studies. Bachmann in East Germany reported a prevalence of 4.6 per million for a prevalence day in $1974^{8}$ and Przuntek in West Germany found a prevalence rate of 2.7 per million for a prevalence day in 1975.13 Thus our prevalence rate of 3.6 per million (1986) lies midway between these two. Clearly if all cases were effectively diagnosed and treated, prevalence should approach the adjusted birth incidence of 17.0 per million over the period 1950-69. 
Table Reported gene frequencies ( $q$ ) of Wilson's disease based on birth incidence from countries with high and low rates of consanguinity by year of report.

\begin{tabular}{|c|c|c|c|c|c|c|c|}
\hline & \multicolumn{3}{|c|}{ Low consanguinity } & \multicolumn{4}{|c|}{ High consanguinity } \\
\hline & $\begin{array}{l}\text { Year of } \\
\text { report }\end{array}$ & $\begin{array}{l}\text { Ref } \\
\text { no }\end{array}$ & $q(\%)$ & & $\begin{array}{l}\text { Year of } \\
\text { report }\end{array}$ & $\begin{array}{l}\text { Ref } \\
\text { no }\end{array}$ & $q(\%)$ \\
\hline Northern Europe & & & & Japan & & & \\
\hline Switzerland & (1973) & 6 & 0.5 & & (1962) & 5 & 0.33 \\
\hline East Germany & (1979) & 8 & 0.53 & & (1965) & 4 & $0 \cdot 3$ \\
\hline West Germany & (1987) & 13 & 0.34 & & (1968) & 5 & 0.66 \\
\hline $\begin{array}{l}\text { Present study } \\
\text { (if no consanguinity) }\end{array}$ & (1991) & & $\begin{array}{l}0.36 \\
0.41\end{array}$ & & (1981) & 9 & 0.55 \\
\hline $\begin{array}{l}\text { (1i no consanguinity) } \\
\text { United States }\end{array}$ & & & & Mediterrane & & & \\
\hline New York & (1953) & 2 & 0.05 & $\begin{array}{l}\text { Sardinia } \\
\text { Israel }\end{array}$ & $\begin{array}{l}(1985) \\
(1990)\end{array}$ & $\begin{array}{l}10 \\
12\end{array}$ & $\begin{array}{l}2 \cdot 7 \\
0.62\end{array}$ \\
\hline
\end{tabular}

Comparison of gene frequencies between countries calculated from birth incidence rates is more interesting and relevant (table). For countries with low rates of consanguinity, the East German study of Bachmann and his colleagues is most widely quoted. ${ }^{8}$ In that report the birth incidence rate of 29 per million is based only on patients born in the year 1950 as accurate statistics of live births were only available for that year. In the present study it was deemed more valid to average birth incidence over two 10 year periods as the number of cases born during each year of the decade varied between zero and three. By basing birth incidence on one year, it is possible that an overestimate or underestimate would be made. A more recent European study is that of Przuntek and Hoffmann in Western Germany who calculated a gene frequency of $0.34 \%$ from birth incidences based only on patients born in $1962 .{ }^{13}$ These authors felt that their ascertainment was less than complete because of only a $45 \%$ response rate to their enquiries. A Swiss study with a high gene frequency of $0.5 \%$ is based on a birth incidence of 22.3 per million derived from 19 cases born in the decade $1946-55 .^{6}$

This figure seems to be a fair reflection of the gene frequency in Switzerland given the 10 year period of study of birth incidence. The gene frequency in this Swiss study is similar to the present results and falls within our $95 \%$ confidence level.

In countries with a high rate of consanguinity, such as Japan ${ }^{49}$ Israel $^{12}$ and Sardinia, ${ }^{10}$ the gene frequencies, as expected, are generally higher than the European studies. For these countries, the Dahlberg formula is applied, with the problem that it assumes a uniform degree of inbreeding within one country. It is unlikely that such uniform consanguinity exists, as Saito admits ${ }^{9}$ and the gene frequency will vary in different parts of the country. The high gene frequency $(2 \cdot 7 \%)$ in Sardinia relates to the high rate of consanguinity in that island. ${ }^{10}$ The recent study from Israel presents a mean gene frequency $(0.62 \%)$ from nine differing ethnic populations within the country varying between $0.21 \%$ for Iraqi Jews to $1.05 \%$ for Druze. ${ }^{12}$

PROBLEMS WITH THE PRESENT STUDY

Given the structure of the health services in the Republic of Ireland, it is unlikely that many cases of Wilson's disease have not been diagnosed. It is probable, however, that a few cases have escaped detection and it is difficult to see how this can be improved without some universal screening procedure at birth. It is also possible that the incidence may be slightly low because of high emigration to the United Kingdom and United States during the period of study. The adjusted birth incidence figures for the decades 1950-59 and 1960-69 are remarkably similar $(17.6$ and 16.4 per million respectively) and therefore it is probable that a reasonably consistent birth incidence over the 20 year period reflects a high degree of ascertainment of diagnosed cases. It is therefore possible to state that the calculated gene frequency is a reasonable approximation of the true gene frequency in the population of the Republic of Ireland.

We are grateful for the advice of Dr Geoffrey Dean in the planning of this study and thank all the Physicians who provided information about patients under their care.

1 Marsden CD. Wilson's disease. Quart $\mathcal{f}$ Med 1987;65: 959-66.

2 Bearn AG. Genetic and biochemical aspects of Wilson's disease. Am ₹ Med Sci 1953;15:442-9.

3 Scheinberg IH, Sternlieb I. Wilson's disease. Philadelphia: WB Saunders, 1984

4 Fukuda K. A genetic aspect of Wilson's disease in Japan. Tohoku $\mathcal{f}$ Exp Med 1965;85:115-9.

5 Arima M, Sano I. Genetic studies of Wilson's disease in Japan. Birth Defects Orig Art Series 1968;4:54-9.

6 Tschumi A, Colombo JP, Moser H. Die Wilsonsche krankheit in der Schweiz, Klinische, genetische und biochemische Untersuchungen. Schweiz Med Wochenschr 1973;103:140-5.

7 Gudmundsson KR. Prevalence and occurrence of some rare neurological diseases in Iceland. Acta Neurol Scand. 1969;45:114-8.

8 Bachmann H, Lossner J, Gruss B, Rucholtz U. Die epidemiologie der Wilsonschen erkrankung in der DDR und die derzeitige problematik einer populations und die derzeitige problematik einer populations genetischen bearbeitung.
Leipzig 1979;31:393-400.

9 Saito T. An assessment of efficiency in potential screening for Wilson's disease. $f$ Epidemiol Commun Hlth, 1981;35:274-80.

10 Giagheddu A, Demelia L, Puggioni G. et al. Epidemiologic study of hepatolenticular degeneration Wilson's disease) in Sardinia. (1902-1983) Acta Neurol Scand 1985;72:43-55.

11 Hevia FJ, Miranda M. The special problem of Wilson's Disease in Costa Rica-an unexpected high prevalence. Gastroenterol Int 1989;2:228.

12 Bonne-Tamir B, Frydman M, Agger MS, et al. Wilson's Disease in Israel: a genetic and epidemiological study. Ann Hum Genet 1990;54:155-68.

13 Przuntek $H$, Hofmann E. Epidemiologische untersuchung zum morbus Wilson in der Bundesrepublik zum morbus Wilson in der

14 Emery AEH. Methodology in medical genetics. 2nd edn, Edinburgh: Churchill Livingstone, 1986.

15 Leck I. Prevention of neural tube defects in an area of high incidence: discussion. In: Dobbing J, ed. Prevention of spine bifida and other neural tube defects. London: Academic Press, 1983:149-51.

16 McKusick UA. Human genetics. New Jersey: Prentice and Hall, 1969. 